\title{
Dukungan Sosial Dan Empati Pada Siswa Berkebutuhan Khusus Berdasar Jenjang Sekolah Menengah Dan Perguruan Tinggi
}

\author{
Yunita Kurniawati \\ Jurusan Psikologi, Fakultas Ilmu Sosial dan Ilmu Politik, Universitas Brawijaya \\ yunita_k@ub.ac.id \\ Faizah \\ Jurusan Psikologi, Fakultas Ilmu Sosial dan Ilmu Politik, Universitas Brawijaya \\ faizah_hermawan@ub.ac.id \\ Ulifa Rahma \\ Jurusan Psikologi, Fakultas Ilmu Sosial dan Ilmu Politik, Universitas Brawijaya \\ ulifa.rahma@ub.ac.id
}

\begin{abstract}
Abstrak
Salah satu faktor yang berperan penting pada pendidikan inklusi adalah teman sebaya. Proses interaksi dengan teman sebaya khususnya di sekolah inklusi membutuhkan empati, karena dapat mendukung ABK mengembangkan kemampuan interpersonalnya. Tidak hanya pada siswa berkebutuhan khusus namun juga pada siswa regular, sehingga penelitian ini bertujuan untuk mengetahui peran dukungan sosial teman sebaya terhadap empati di sekolah inklusi. Metode penelitian yang digunakan dalam penelitian ini adalah kuantitaif kausalitas. Sebanyak 454 siswa SMP, SMA dan mahasiswa Perguruan Tinggi inklusi mengisi skala dukungan sosial teman sebaya dan skala empati. Data lalu dianalisis menggunakan analisis regresi sederhana. Hasil penelitian ini menunjukkan bahwa terdapat pengaruh yang signifikan dukungan sosial teman sebaya terhadap empati pada siswa SMP $(23,3 \%)$, SMK $(21,2 \%)$, dan mahasiswa perguruan tinggi di sekolah inklusi $(5,8 \%)$.
\end{abstract}

Kata kunci : dukungan sosial teman sebaya., empati., siswa abk., sekolah inklusi.

\section{Pendahuluan}

Kesadaran masyarakat mengenai pentingnya pendidikan pada anak mulai meningkat, tak terkecuali pada pendidikan inklusi. Jumlah Anak Berkebutuhan Khusus (ABK) Di Provinsi Jawa Timur pada Tahun 2017 sebanyak 5,9 ribu jiwa, jumlah tersebut menempati urutan ke enam terbanyak setelah Provisi Riau, Jambi, Kepulauan Riau, Jawa Tengah dan Nusa Tenggara Timur (lokadata.beritagar.id). 
Salah satu kota di Provinsi Jawa Timur adalah kota Malang, yang memiliki sekolah inklusi sebanyak 130 pada tahun 2014, yang menampung lebih kurang 1000 siswa berkebutuhan (www.malangpost.com). Data tersebut menunjukkan bahwa di kota Malang sendiri telah tersedia cukup banyak sekolah inklusi. Hal tersebut telah sesuai dengan surat edaran Dirjen Dikdakmen Depdiknas No. 380/C.C6/MN/2003 tanggal 20 Januari 2003 perihal pendidikan inklusif, maka diselenggarakan dan dikembangkan di setiap kabupaten/kota sekurang-kurangnya tiga sekolah yang terdiri dari SMP, SMA, dan SMK. Sekolah inklusi merupakan sebuah lembaga yang menyediakan pelayanan pendidikan bagi peserta didik yang mempunyai kebutuhan pendidikan khusus di sekolah regular (SMP, SMU, dan SMK) yang tergolong luar biasa baik dalam arti kelainan, lamban belajar maupun berkesulitan belajar lainnya (Marthan, 2007).

Tujuan sekolah inklusi sendiri yaitu membuat anak belajar dalam menyesuaikan diri dengan lingkungan yang beragam, dan nantinya akan membuat mereka siap untuk terlibat pada aktivitas normal di masyarakat luas. Namun cukup banyak kendala yang dihadapi untuk mencapai tujuan tersebut, diantaranya terbatasnya jumlah guru atau tenaga pendidik, tantangan dari pihak keluarga, maupun penyesuaian diri siswa berkebutuhan khusus. Siswa berkebutuhan khusus atau ABK adalah anak yang dalam proses pertumbuhan atau perkembangannya mengalami hambatan baik secara fisik, mental-intelektual, sosial maupun emosional dibanding dengan anak-anak lain seusianya, sehingga mereka memerlukan pelayanan pendidikan khusus (Mangunsong, 2011).

Salah satu faktor yang mempengaruhi penyesuaian diri terutama pada siswa berkebutuhan khusus adalah lingkungan kelas, dimana penerimaan atmosfer kelas yang positif merupakan faktor keberhasilan sekolah inklusi (Scruggs \& Mastropieri, 1994; Frederickson \& Cline, 2009, dalam Hasan \& Andayani, 2014; Schwab, 2017). Penerimaan atmosfer kelas pada penelitian ini adalah teman sebaya. Lingkungan sekolah dan teman sebaya merupakan lingkup mikrosistem dalam kehidupan anak termasuk siswa $\mathrm{ABK}$, sehingga peran keduanya dalam interaksi sosial siswa cukup penting (Hidayati, 2011). 
Dukungan teman sebaya juga merupakan tantangan pada pendidikan inklusi terutama pada aspek sosial emosional (Mangunsong, 2011) yang meliputi a. pengembangan interaksi dan komunikasi yang bermakna merupakan dasar bagi semua hubungan sosial dan pembelajaran; b. mengembangkan hubungan pertemanan yang tulus; mengatasi kesepian; dan c. mengembangkan harga diri.

Siswa banyak menghabiskan waktu bersama teman-teman disekolah (Santrock, 2003), sehingga dapat dilihat peranan teman sebaya dalam kehidupan siswa, tak terkecuali pada siswa berkebutuhan khusus. Namun, pada beberapa penelitian menjelaskan bahwa siswa berkebutuhan khusus biasanya memiliki partisipasi sosial yang rendah, karena merasa memiliki sedikit teman, dan kesepian karena perasaan kurang diterima oleh teman sebaya (Bossaert, Colpin, Pijl, \& Petry, 2011). Siswa regular pada sekolah inklusi juga membatasi interaksi sosial pada siswa berkebutuhan khusus. Hal tersebut sesuai dengan hasil observasi peneliti pada salah satu SMP di Malang tahun 2017 bahwa pergaulan siswa regular dengan teman berkebutuhan khusus menunjukkan lemahnya esteem and information support seperti sikap kurang menghargai keberadaan teman berkebutuhan khusus di kelasnya, menertawakan teman berkebutuhan khusus, termasuk kurang memberikan informasi saat memiliki informasi/pengetahuan akan keilmuannya. Permasalahan tersebut menunjukkan tantangan pada pendidikan inklusi khususnya pada interaksi sosial di lingkup sekolah.

Penelitian Hasan dan Handayani (2014) menyatakan bahwa terdapat hubungan antara dukungan sosial teman sebaya dengan penyesuaian diri siswa tunarungu di sekolah inklusi. Dukungan sosial dapat diartikan sebagai kenyamanan, perhatian, ataupun bantuan yang diterima individu dari orang lain, dimana orang lain disini bisa berarti individu secara perorangan ataupun kelompok (Sarafino, 1994).

Sarafino (1994) mengemukakan bahwa dukungan sosial dapat berasal dari berbagai sumber seperti pasangan/kekasih, keluarga, teman, terapis, dokter, atau organisasi masyarakat. Fokus penelitian ini adalah dukungan sosial yang bersumber pada teman sebaya sebagai social support network siswa di sekolah. Social Support Network atau jaringan dukungan sosial adalah seseorang yang 
dapat diminta bantuan dan siapa yang akan memberikan bantuan bila diperlukan (Breckler, Olson, \& Wiggins, 2006). Jaringan sosial teman sebaya yang memiliki usia yang sama memainkan peran khusus dalam perkembangan sosioemosional individu. Salah satu fungsi yang paling penting dari dukungan teman sebaya adalah untuk memberikan sumber informasi dan perbandingan tentang dunia di luar keluarga. Hubungan positif dengan teman sebaya merupakan peran yang penting agar perkembangan individu menjadi normal (Howes \& Tonyan, dalam Santrock, 2009).

Penelitian Miller dan Miller (Bond \& Castagnare, 2006) serta Schwab (2017) mengemukakan pentingnya dukungan sosial teman sebaya, dimana pada penelitiannya menemukan bahwa dengan adanya teman sebaya akan mendukung anak dengan disabilitas dan memberikan sikap yang positif pada siswa berkebutuhan khusus. Dukungan sosial teman sebaya juga merupakan salah satu bentuk intervensi dan pendidikan yang efektif dengan cara memotivasi mereka untuk belajar bersama.

Berdasarkan penelitian terdahulu, dukungan sosial teman sebaya dapat mendukung pendidikan inklusi seperti meningkatkan penerimaan, komunikasi, penyesuaian diri dan keterampilan sosial (Bond \& Castagnera, 2006). Jalinan interaksi sosial yang baik akan mampu mengembangkan penyesuaian diri dan keterampilan sosial individu. Empati merupakan dasar utama keterampilan interaksi individu (Bohart \& Greenberg, 1997). Snyder dan Lopez (2007) menjelaskan bahwa empati merupakan respon emosi yang berasal dari keadaan emosi seseorang atau kondisi emosinya, yang sejajar dengan keadaan emosi orang lain sehingga diartikan empati merupakan kemampuan untuk mengalami emosi yang sama dengan orang lain. Hoffman (2000) menggambarkan perkembangan empati berkaitan dengan kemampuan seseorang untuk membedakan antara dirinya dengan orang lain. Ia membagi empati menjadi empat tahap, pada tahap keempat individu telah mampu untuk berempati bukan hanya pada individu lainnya, namun juga pada kelompok dan masyarakat, termasuk dengan teman sebaya. Empati penting bagi kemampuan individu untuk menjalin interaksi secara sosial dengan teman sebaya. Ketika individu mampu berempati, maka ia dapat memahami efek 
emosional dan sosial perilakunya pada orang lain. Ia juga mampu menginterpretasi petunjuk-petunjuk sosial teman sebaya secara akurat dan memahami perhatian yang diberikan teman sebaya. Sebaliknya, anak yang kurang memiliki kemampuan berempati cenderung menunjukkan perilaku agresi terhadap orang lain. Hal tersebut berkaitan dengan kurangnya kemampuan untuk menginterpretasi perasaan dan perilaku orang lain (CCHP, 2010).

Berdasarkan pemaparan diatas dalam penelitian ini peneliti ingin melihat peran dukungan sosial teman sebaya terhadap empati pada siswa ABK di sekolah inklusi menengah pertama (SMP), sekolah inklusi menengah atas (SMA), dan pada mahasiswa $\mathrm{ABK}$ di perguruan tinggi inklusi.

\section{Metode}

Fokus penelitian ini adalah melihat peran dukungan sosial teman sebaya terhadap empati pada siswa ABK di sekolah inklusi pada jenjang pendidikan sekolah menengah dan Perguruan Tinggi. Metode penelitian yang digunakan adalah metode kuantitatif (Balnaves \& Caputi, 2001).

Populasi dalam penelitian ini adalah siswa sekolah inklusi, yaitu siswa SMP, SMA dan Perguruan Tinggi di kota Malang. Pemilihan sampel penelitian dilakukan melalui metode purposive sampling. Adapun partisipan dalam penelitian ini sejumlah 454 siswa ( $\mathrm{SMP}=192 ; \mathrm{SMA}=114 ; \mathrm{PT}=148)$.

Metode pengumpulan data dengan menggunakan skala psikologi. Teknik ini memberikan tanggungjawab kepada responden untuk membaca dan menjawab pertanyaan. Skala psikologi didistribusikan dengan cara disampaikan secara langsung oleh asisten peneliti. Skala yang disebar terdiri dari 2 skala, yaitu skala dukungan sosial teman sebaya dan skala empati.

1. Skala dukungan sosial teman sebaya

Skala dukungan sosial teman sebaya mengacu pada konsep Sarafino (1994) yang mengukur aspek-aspek sebagai berikut: 
Tabel 1. Aspek-aspek dukungan sosial

\begin{tabular}{|c|c|c|}
\hline No & Aspek & Pengertian \\
\hline 1. & $\begin{array}{l}\text { Dukungan Emosional } \\
\text { (Emotional Support) }\end{array}$ & $\begin{array}{l}\text { Jenis dukungan ini dilakukan dengan melibatkan ungkapan } \\
\text { rasa empati, kepedulian, dan perhatian terhadap seseorang } \\
\text { sehingga memberikan perasaan nyaman, ketentraman hati, } \\
\text { dan perasaan dicintai yang membuatnya merasa lebih baik. } \\
\text { Dukungan emosional adalah ekspresi dari afeksi, } \\
\text { kepercayaan, perhatian, dan perasaan didengarkan. Kesediaan } \\
\text { untuk mendengarkan keluhan seseorang akan memberikan } \\
\text { dampak positif, yaitu sebagai sarana pelepasan emosi dan } \\
\text { mengurangi kecemasan, serta membuat individu merasa } \\
\text { dihargai, diterima, dan diperhatikan. }\end{array}$ \\
\hline 2. & $\begin{array}{l}\text { Dukungan Penghargaan } \\
\text { (Esteem Support) }\end{array}$ & $\begin{array}{l}\text { Dukungan ini terjadi lewat ungkapan penghargaan positif } \\
\text { untuk individu yang bersangkutan, dorongan maju dan } \\
\text { perbandingan positif individu dengan orang-orang lain. } \\
\text { Orford berpendapat bahwa dukungan penghargaan } \\
\text { dititikberatkan pada adanya suatu pengakuan, penilaian yang } \\
\text { positif, dan penerimaan terhadap individu. Menurut Cohen } \\
\text { (dalam Sarafino, 1994), jenis dukungan ini dilakukan melalui } \\
\text { ekspresi sambutan positif orang-orang yang berada di } \\
\text { sekitarnya, pemberian dorongan atau pernyataan setuju } \\
\text { terhadap ide-ide dan perasaan individu. Dukungan ini } \\
\text { membuat seseorang merasa berharga, kompeten, dan dihargai. }\end{array}$ \\
\hline 3. & $\begin{array}{l}\text { Dukungan Instrumental } \\
\text { (Instrumental Support) }\end{array}$ & $\begin{array}{l}\text { Jenis dukungan ini berupa bantuan yang sifatnya nyata dan } \\
\text { langsung yaitu dapat berupa jasa, waktu, meminjamkan uang, } \\
\text { dan membantu mengerjakan tugas seseorang ketika sedang } \\
\text { stres. Dukungan instrumental mengacu pada penyediaan } \\
\text { barang atau jasa yang dapat digunakan untuk memecahkan } \\
\text { masalah-masalah praktis. Dukungan ini membantu individu } \\
\text { untuk melaksanakan aktivitasnya. }\end{array}$ \\
\hline 4. & $\begin{array}{l}\text { Dukungan Informasi } \\
\text { (Informational Support) }\end{array}$ & $\begin{array}{l}\text { Jenis dukungan ini mencakup pemberian nasehat, petunjuk, } \\
\text { saran-saran, ataupun umpan balik tentang apa yang telah } \\
\text { dikerjakan. Melalui interaksi dengan orang lain, individu akan } \\
\text { dapat mengevaluasi dan mempertegas keyakinannya dengan } \\
\text { membandingkan pendapat, sikap, keyakinan, dan perilaku } \\
\text { orang lain. Dukungan ini membantu individu mengatasi } \\
\text { masalah dengan cara memperluas wawasan dan pemahaman } \\
\text { individu terhadap masalah yang dihadapi. Informasi tersebut } \\
\text { diperlukan untuk mengambil keputusan dan memecahkan } \\
\text { masalah secara praktis. }\end{array}$ \\
\hline 5. & $\begin{array}{l}\text { Dukungan } \\
\text { Sosial } \\
\text { Support) }\end{array}$ & $\begin{array}{l}\text { Jenis dukungan ini diberikan dengan cara membuat kondisi } \\
\text { agar seseorang merasa menjadi bagian dari suatu kelompok } \\
\text { yang memiliki persamaan minat dan aktivitas sosial. Jenis ini } \\
\text { mencakup perasaan keanggotaan dalam kelompok. Dukungan } \\
\text { jaringan sosial ini juga disebut sebagai dukungan } \\
\text { persahabatan (Companionship Support) yang merupakan } \\
\text { suatu interaksi sosial yang positif dengan orang lain, dimana } \\
\text { memungkinkan individu dapat menghabiskan waktu dengan } \\
\text { individu lain dalam suatu aktivitas sosial maupun hiburan. } \\
\text { Berasarkan penelitian yang dilakukan oleh Cohen dan Wills }\end{array}$ \\
\hline
\end{tabular}


(1992), dukungan jaringan sosial akan membantu individu untuk mengurangi stres yang dialami karena dapat memenuhi kebutuhan akan persahabatan dan kontak sosial dengan orang lain.

Skala dukungan sosial teman sebaya memiliki reliabilitas sebesar 0,886 yang menunjukkan bahwa skala tersebut reliabel.

2. Skala empati

Skala empati pada penelitian ini diadaptasi dari Index of empathy for children and adolescents oleh Bryant (1982) yang terdiri dari 22 butir pernyataan dengan reliabilitas 0,705 yang berarti instrumen skala empati reliabel.

Teknik analisa data yang digunakan dalam penelitian ini adalah analisis regresi linier sederhana. Analisis regresi ialah suatu teknik untuk menganalisis hubungan sebab akibat yang terjadi pada variabel bebas dan variabel terikat (Rutherford, dalam Sarwono, 2007). Data dalam penelitian ini diolah dengan menggunakan program komputer SPSS (Statistics for Products and Services Solution) for windows 16.0.

\section{Hasil dan Pembahasan}

Hasil penelitian menunjukkan terdapat peran dukungan sosial teman sebaya terhadap empati pada siswa SMP, SMA dan mahasiswa Perguruan Tinggi. Hal tersebut dapat dilihat pada tabel 2.

Tabel 2. Peran dukungan sosial teman sebaya tehadap empati

\begin{tabular}{cccc}
\hline \multirow{2}{*}{$\begin{array}{c}\text { Jenjang } \\
\text { pendidikan }\end{array}$} & \multicolumn{3}{c}{ Dukungan Sosial terhadap empati } \\
\cline { 2 - 4 } & Rsquare & $\mathbf{t}$ & $\mathbf{s i g}$ \\
\hline SMP & 0,233 & 5,230 & 0,001 \\
SMA & 0,212 & 5,491 & 0,001 \\
PT & 0,058 & 3,001 & 0,003 \\
\hline
\end{tabular}

Tabel 2 menjelaskan adanya peran dukungan sosial teman sebaya terhadap empati pada jenjang sekolah menengah dan perguruan tinggi (t SMP: 5,230, dengan $\mathrm{p}=0,01<0,05$; t SMA: 5,491, dengan $\mathrm{p}=0,01<0,05$; serta t PT: 3,001, dengan $\mathrm{p}=0,03<0,05)$. Peran dukungan sosial teman sebaya pada masingmasing jenjang pendidikan adalah sebesar $23,3 \%$ pada siswa SMP, $21,2 \%$ pada 
siswa SMA, serta 5,8\% pada mahasiswa Perguruan Tinggi terhadap empati pada siswa berkebutuhan khusus.

Hasil penelitian ini sesuai dengan pendapat Pramuaji (2014) bahwa dengan peningkatan dukungan dan interaksi teman sebaya yang pada akhirnya diharapkan berpengaruh pada peningkatan kemampuan empati. Myers (dalam Hobfoll, 1986) mengemukakan bahwa salah satu faktor penting yang mendorong seseorang untuk memberikan dukungan yang positif, salah satunya adalah empati, yaitu turut merasakan kesusahan orang lain dengan tujuan mengantisipasi emosi dan memotivasi tingkah laku untuk mengurangi kesusahan dan meningkatkan kesejahteraan orang lain.

Pengembangkan penyesuaian diri dan keterampilan sosial individu perlu dilakukan untuk menjalin interaksi sosial dengan baik. Empati merupakan dasar utama keterampilan interaksi individu. Empati penting bagi kemampuan anak untuk menjalin interaksi secara sosial dengan teman sebaya. Ketika anak mampu berempati, maka ia dapat memahami efek emosional dan sosial perilakunya pada orang lain. Ia juga mampu menginterpretasi petunjuk-petunjuk sosial teman sebaya secara akurat dan memahami perhatian yang diberikan teman sebaya sebaliknya, anak yang kurang memiliki kemampuan berempati cenderung menunjukkan perilaku agresi terhadap orang lain. Hal ini berkaitan dengan kurangnya kemampuan untuk menginterpretasi perasaan dan perilaku orang lain (CCHP, 2010). Berdasarkan penelitian terdahulu, dukungan sosial teman sebaya dapat mendukung pendidikan inklusi seperti meningkatkan penerimaan, komunikasi, penyesuaian diri dan keterampilan sosial (Bond \& Castagnera, 2006). Hal tersebut juga didukung oleh penelitian Ishak dkk (2014) dan Schwab (2017) bahwa keterampilan sosial, dukungan terhadap disabilitas berkorelasi positif terhadap empati siswa khususnya disekolah inklusi.

Dari hasil analisa data bahwa dukungan sosial teman sebaya memiliki peran sebesar 23,3\% terhadap empati pada siswa ABK di SMP. Pada jenjang pendidikan SMA dukungan sosial teman sebaya memiliki peran sebesar $21,2 \%$ terhadap empati pada siswa ABK. Adapun dukungan sosial teman sebaya memiliki peran sebesar 5,8\% terhadap empati pada siswa ABK di Perguruan 
Tinggi. Sedangkan $77,7 \%$ pada jenjang pendidikan SMP,78,8\% pada jenjang pendidikan SMA dan $94,2 \%$ pada jenjang pendidikan Perguruan Tiggi dipengaruhi oleh faktor faktor yang lain yaitu norma dan nilai sosial serta norma dan nilai sosial. Hal ini didukung oleh pendapat Myers (dalam Hobfoll, 1986) mengemukakan bahwa sedikitnya ada tiga faktor penting yang mendorong seseorang untuk memberikan dukungan yang positif, diantaranya: a) empati, yaitu turut merasakan kesusahan orang lain dengan tujuan mengantisipasi emosi dan memotivasi tingkah laku untuk mengurangi kesusahan dan meningkatkan kesejahteraan orang lain. b) Norma dan nilai sosial, yang berguna untuk membimbing individu untuk menjalankan kewajiban dalam kehidupan. c) Pertukaran sosial, yaitu hubungan timbal balik perilaku sosial antara cinta, pelayanan, informasi. Keseimbangan dalam pertukaran akan menghasilkan hubungan interpersonal yang memuaskan. Pengalaman akan pertukaran secara timbal balik ini membuat individu lebih percaya bahwa orang lain akan menyediakan bantuan.

\section{Kesimpulan dan Saran}

\section{Kesimpulan}

Berdasarkan penelitian tentang peran dukungan sosial teman sebaya dalam menjelaskan empati pada siswa berkebutuhan khusus disekolah inklusi, maka dapat diperoleh kesimpulan yaitu: :

1. Hasil analisis regresi linier sederhana menunjukkan adanya peran yang signifikan $(0,001 \leq 0,05)$ antara dukungan sosial teman sebaya dengan empati pada siswa SMP inklusi, dimana dukungan sosial teman sebaya memiliki peran sebesar 23,3\% terhadap empati pada siswa ABK

2. Hasil analisis regresi linier sederhana menunjukkan adanya peran yang signifikan $(0,001 \leq 0,05)$ antara dukungan sosial teman sebaya dengan empati pada siswa SMA inklusi, dimana dukungan sosial teman sebaya memiliki peran sebesar $21,2 \%$ terhadap empati pada siswa ABK

3. Hasil analisis regresi linier sederhana menunjukkan adanya peran yang signifikan $(0,003 \leq 0,05)$ antara dukungan sosial teman sebaya dengan empati 
pada mahasiswa Perguruan Tinggi inklusi, dimana dukungan sosial teman sebaya memiliki peran sebesar 5,8\% terhadap empati pada siswa ABK

\section{Saran}

Berdasarkan penelitian yang telah dilakukan dan pembahasan yang telah diuraikan sebelumnya, peneliti mengajukan beberapa saran, yaitu:

1. Peneliti selanjutnya dapat meneliti mengenai peran dukungan sosial dengan variabel lainnya seperti norma dan nilai sosial di sekolah

2. Peneliti selanjutnya dapat memperluas jenjang pendidikan pada sampel penelitian yaitu sekolah dasar

3. Peneliti selanjutnya dapat meneliti kedua variabel (dukungan sosial teman sebaya dan empati) terhadap individu ABK pada setting pekerjaan

4. Bagi pihak sekolah inklusi dapat meningkatkan pemahaman siswa mengenai ABK dan memfasilitasi interaksi sosial antara siswa ABK dengan siswa pada umumnya, seperti memberikan pelatihan empati.

\section{DAFTAR PUSTAKA}

Balnaves, M \& Caputi, P (2001). Quantitative Methods. London: Sage. Publication

Bohart, A., \& Greenberg, L.S. (1997). Empathy reconsidered. Washington DC. American Psychological Association

Bond, R., \& Castagnera, E. (2006). Peer support and inclusive education: An underutilized resource. Theory into practice, 45 (3), 224-229

Bossaert, G., Colpin, H., Pijl, S. P., \& Petry, K. (2011). Loneliness among students with special educational needs in mainstream seventh grade. Research in Developmental Disabilities, 33 (2011), pp. 1888-1897

Breckler, S. J., Olson, J., \& Wiggins, E. (2006). Social psychology alive. Boston: Thomson Wadsworth

California Childcare Health Program. (2010). Nurturing empathy. California Childcare Health Program, 23(3), 1-8

Cohen, S. et al. (2000). Social Relationships and Health. Dalam Social Support Measurement and Intervention-A Guide for Health and Social Scientiest (ed Sheldon Cohen et all). Newyork: Oxford University Press, Inc. 
Cohen, S., \& Willis, T.A. (1992). Stress, social support and the buffering hypothesis. Psychological Bulletin, 98(2),310-357

Hasan, S. A., \& Handayani, M. M. (2014). Hubungan antara dukungan sosial teman sebaya dengan penyesuaian diri siswa tunarungu disekolah inklusi. Jurnal Psikologi pendidikan dan perkembangan, 3(2), 128-135

Hidayati, N. (2011). Dukungan sosial bagi anak berkebutuhan khusus. Jurnal Insan, 13 (1), 12-20

Hobfoll, S, E. (1986). Stress, social support and women : the series in clinical and community psychology. New York : Herper \& Row.

Hoffman, M. L. (2000). Empathy and moral development: Implication for caring and social justice. Cambridge: Cambridge university press

Ishak, N. M., Abidin, M. H. Z., \& Bakar, A. Y. A. (2014). Dimensions of social skills and their relationship with empathy among gifted and talented students in Malaysia. Social and Behavioral Sciences 116, pp. 750 - 75. doi: 10.1016/j.sbspro.2014.01.292

Jumlah GPK belum sebanding dengan ABK. April, (2014). www.malangpost.com. Diakses pada 7 Mei 2015.

Mangunsong, F. (2011). Psikologi dan pendidikan anak berkebutuhan khusus. Jilid pertama. Depok. LPSP3UI.

Marthan, L. K. (2007). Manajemen Pendidikan Inklusif. Jakarta: Dirjen Dikti.

Santrock, J. W. (2009). Remaja. Edisi 11. Jakarta: Erlangga.

Sarafino, E. P. (1994). Health psychology. New York: John Wiley \& Sons, Inc.

Sarwono. (2007). Psikologi remaja. Jakarta : Raja Grafindo Persada

Schonert- Reichl, K. (2011). Promoting empathy in school-aged children: Current approaches and implications for practice. School rampage shootings and other youth disturbances: early preventive interventions. New York. Routledge.

Schwab, S. (2017). The impact of contact on students' attitudes towards peers with disabilities. Research in Developmental Disabilities 62, 160-165.

Scruggs, T. E., \& Mastropieri, M. A. (1994). The construction of scientific knowledge by students with mild disabilities. The Journal Of Special Education, 28 (3). https://doi.org/10.1177/002246699402800306 
Snyder, C. R., \& Lopez, S. J. (2007). Positive psychology: The scientific and practical explorations of human strengths. California. Sage publication, Inc.

Orford, J. (1992). Community psychology : Theory \& practise. West Sussex : John Wiley \&Suns. Ltd 